DOI 10.18551/rjoas.2019-08.09

\title{
FINANCIAL DISTRESS, MACROECONOMIC FACTORS AND ITS EFFECT TOWARDS STOCK PRICE IN MINING COMPANIES OPERATING IN THE COAL SUBSECTOR REGISTERED IN INDONESIA STOCK EXCHANGE FOR PERIOD OF 2013-2017
}

\author{
Mulyanti Siti Yanti ${ }^{\star}$, Student \\ Anggraeni Lukytawati, Lecturer \\ School of Business, IPB University, Indonesia \\ Sasongko Hendro, Lecturer \\ School of Economics, University of Pakuan, Indonesia \\ *E-mail: sitiyanti75@gmail.com
}

\begin{abstract}
Stock price is one of company performance indicators. There are many factors influencing the stock price, so this will be a concern for a company to focus and strive to maintain the stock price. The purpose of this study was to analyze the effect of financial distress, financial characteristics and macroeconomic on stock prices of coal company as listed on Indonesia Stock Exchange (IDX) during the period of 2013-2017. This paper uses panel data regression with fixed effect model. Eleven coal companies were selected as samples. The finding of the research showed that Z-score, financial characteristic, such as ROA and CFO which have positive and significant effect on stock prices, while macroeconomic variables such as interest rate, exchange rate and inflation have negative and significant effect on stock prices.
\end{abstract}

\section{KEY WORDS}

Financial distress, Z-Score, stock prices, panel data regression.

The fast growth of technology and global economy has insisted the business industry to keep up with its development. The fast growth and development have led to tougher competition in the market. The company needs to have high adaptability to compete in the domestic, regional, and international business industry. A company is expected to not only have high levels of adaptability, but it is also expected to maintain their own sustainability in the midst of constant change (Sinambela 2009). Any changes in the companies' performances would be reflected from their ability to accommodate and adapt to every change. For public companies, its performances would be reflected through their stock prices that have been registered in the stock exchange.

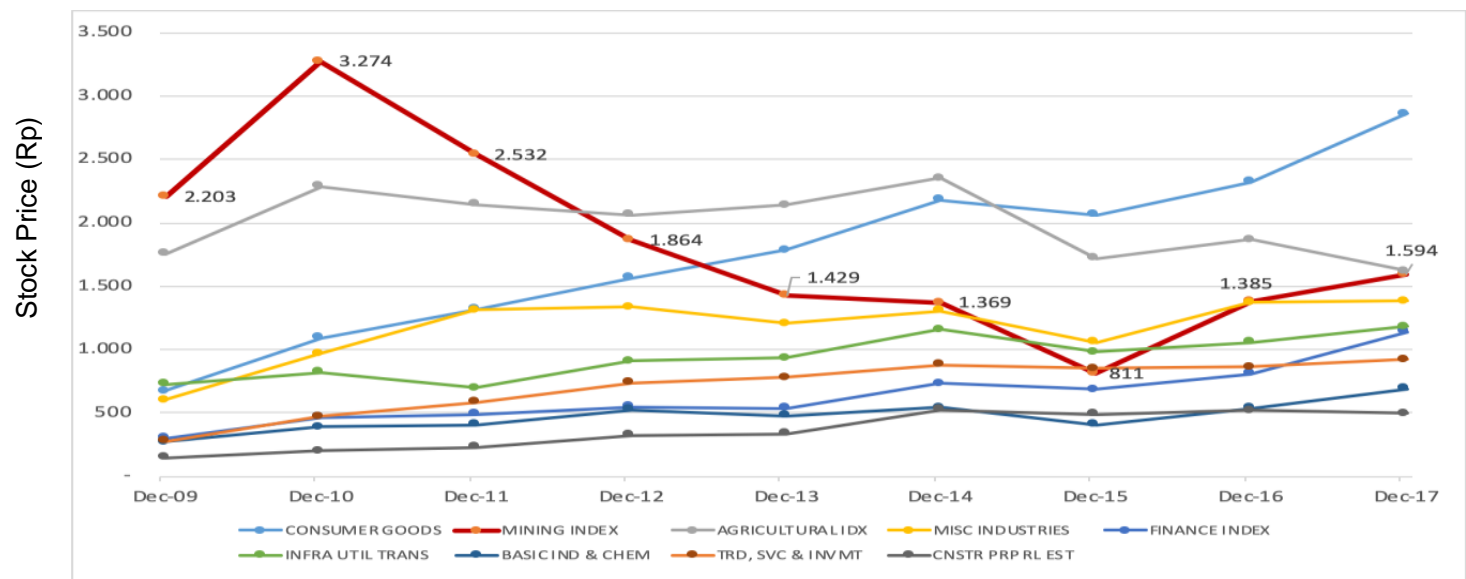

Figure 1 - Sectoral Stock Performances from 2007 until 2017 (Source: IDX, 2018) 
In recent years, the mining sector has experienced one of the sharpest declines in stock price performance compared to other sectors, with an average decline of $23 \%$. The downturn global economy and commodity prices that have not grown until 2017 are suspected to several reasons behind the decline of stock price performance within the mining sector (World Bank 2018). In addition, the mining sector has not seen any significant increase in the production, which can also led to the decline of stock price performance in the mining sector. Figure 1 shows stock performances of Stock Exchange by sector from 2007 until 2017.

One of the subsectors in a mining sector is the coal industry. Indonesia is one the largest coal producers and exporters in the world. Since 2005, Indonesia has become the leading exporter of thermal coal in the world, surpassing Australia. When the coal industry experienced a boom in 2000s, companies have gained significant amount of profit. Most of the profits gained were triggered by economic growth, especially economic growth in China and other developing countries that needed large amount of energy sources, in which led to an increase of coal commodity prices. Nevertheless, this favorable situation turned around during the global financial crisis in 2008, which led to the decrease of commodity prices, rise of interest rates, and weakens the currency exchange rate. Indonesia is inseperable from those external factors because commodity exports, especially coal and palm oil, contribute to nearly $50 \%$ of Indonesia's total export activity. In the second semester of 2009 until early 2011, global coal prices experienced a sharp rebound. Nonetheless, decline in global economic activity has also decreased the demand for coal, which once again caused a sharp decrease of coal prices in early 2011 until mid-2016 and also a decrease of stock performance (www.indonesia-investments.com).

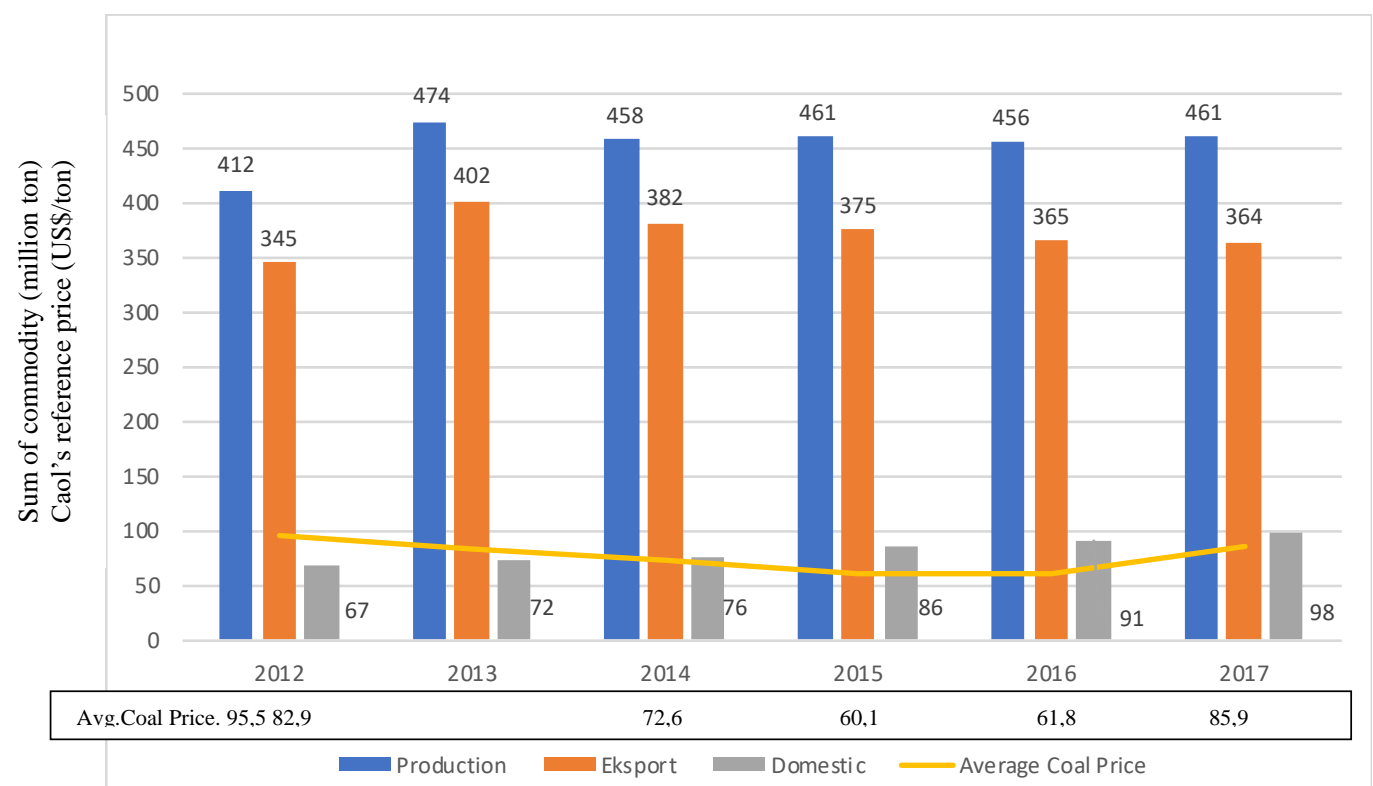

Figure 2 - Average of Production, Export, Domestic and HBA from 2012 until 2017 (Source: Indonesia Coal Mining Association (APBI) \& Ministry of Energy and Mineral Resources)

Figure 2 shows the amount of coal production from 2012 until 2017; in which around $80 \%$ of it is a commodity export. The reference price for coal, referred as Harga Batubara Acuan (HBA), was declined in 2012 and also an increase in 2017. Furthermore, correction of HBA occurred in 2015, which caused numerous coal companies to experience net loss. According to Indonesia Banking Statistics, the banking's amount of credit and value of Non Performing Loan (NPL) towards the mining industry continues to increasefrom 2013 until 2017 (Table 1). In 2016 and 2017, the NPL ratio was $7.2 \%$ and $6.2 \%$ respectively. Those NPL values are above the $5 \%$ limit that has been set by Financial Services Authority (OJK). This illustrates that numerous companies within that particular sector were experienced difficulties in liquidity. 
Table 1 - Banking's Credit and NPL towards the Mining Sector

\begin{tabular}{cccc}
\hline Year & NPL Value (billion rupiah) & Credit (billion rupiah) & NPL Ratio(\%) \\
\hline 2013 & 126.826 & 1.920 & $1,5 \%$ \\
2014 & 141.824 & 3.574 & $2,5 \%$ \\
2015 & 135.273 & 5.582 & $4,1 \%$ \\
2016 & 126.335 & 9.043 & $7,2 \%$ \\
2017 & 113.622 & 7.019 & $6,2 \%$ \\
\hline
\end{tabular}

Source: Indonesia Banking Statistics.

Avdalovic and Milencovic (2017) explained that stock prices could be influenced by financial performance, especially leverage and liquidity ratio in Beogard Stock Exchange. A decline in financial performance could initially indicate that companies in the mining industry are experiencing financial distress. Wahyuni et al. (2016), Lestari et al. (2016), Apergis et al. (2011) and Zhao (2015) studies described that financial distress could affect a mining company's stock price. If a company is experiencing financial distress and they could not handle those distresses properly, then it could lead to a disruption of business activities. Evidently, Ullah et al. (2017) illustrated that macroeconomic variables such as exchange rate, foreign currency reserve, and interest rate, are statistically significant in affecting stock market performance.

Various researches has discussed financial performance, internal and external factors, and its impact towards stock price, including companies that are experiencing financial distress with different results. Several researches have shown positive relationship between Earning per Share (Wahyuni et al. (2016) and (Perdana et al. (2013)), macroeconomic factors such as interest rate and exchange rate (Ullah et al. (2017) towards stock price. However, other studies have shown negative relationship between Earning per Share (Avdalovic\&Milenkovic (2017)), macroeconomic factors such as interest rate and exchange rate (Artha et al. (2014) and Pardede et al. (2016)) towards stock price.

With discrepancies of results among previous studies, this paper would like to investigate further factors that might have an impact on stock price. Hence, this study will focus on analyzing variables such as financial characteristics, financial distress, macroeconomic factors, and its effect towards stock price of mining companies operating in the coal subsector. The purposes of this study are:

1. To analyze financial characteristics of mining companies operating in the coal subsector that are registered in Indonesia Stock Exchange (BEI) from 2013 until 2017;

2. To acknowledge and identify whether financial distress exists within mining companies operating in the coal subsector that are registered in Indonesia Stock Exchange (BEI) from 2013 until 2017;

3. To analyze the effects of financial characteristics, financial distress, and macroeconomic factors towards stock price of mining companies operating in the coal subsector that are registered in Indonesia Stock Exchange (BEI) from 2013 until 2017.

\section{LITERATURE REVIEW}

In most cases, a company's main purpose is to maximize profit and minimize their loss. Furthermore, a company's success is determined by its own performance. Hence, a company's performance can be evaluated by their financial and non-financial performance. For instance, financial performance can be measured by analyzing financial statements. Financial statements are one of the tangible forms that could indicate a company's performance, especially regarding the management of their finances. A financial statement serves as means of communication, a tool for the company to show their accountability towards stakeholders, an indicator of success, and also a crucial aspect in decision-making processes (Harahap 2007). Furthermore, financial performance of a company would also indicate the level of financial health that the company has. Fahmi (2011) explained that a 
financial statement is used as information that could illustrate the company's current condition, in which it would correlate with their performances. Analysing financial statement can be done through comparing ratios. According to Fahmi (2011), financial ratios are divided into several categories such as liquidity ratios (i.e., Current Ratio (CR) and Quick Ratio), leverage ratios (i.e., Debt to Capital, Total Debt to Equity Ratio (DER), Total Debt to Total Assets Ratio), utilization turnover ratios (i.e., Receivable Turnover, Total Asset Turnover), probability ratios (i.e., Return on Assets (ROA) and Net Profit Margin), and growth ratios (i.e., Earning per Share (EPS) and Dividend per Share)

Financial distress can be described as a condition when a company is experiencing financial difficulties or crisses which would be reflected in their inability to pay and distribute their obligation to the stakeholders. Sun et al. (2014) stated that financial distress can be defined as a condition where a company has financial struggles, such as being unable to pay off their debts, excessive account withdrawal, and bank deposit overdraft. Furthermore, from legal prespective, a financial distress is recognized when a company is declared bankrupt based on the national company law because they are not able to fulfill their obligation towards its debtors. Financial distress is classified into three categories, which are 'light', 'moderate', and 'bankrupt'.

The performance of Jakarta Composite Index $(\mathrm{JCl})$ or more commonly known as Indeks Harga Saham Gabungan (IHSG), which has declined in recent years, could point out and indicate companies that are continuously experiencing financial distress could face bankruptcy in the long run. Bose (2006) explained that financial distress could be seen from the evaluation results of a company's stock price in the capital market. Davydenko and Franks (2008) and Djankov et al. (2008) have empirically established that the design of bankruptcy codes affects the bargaining power of creditors and debtors during difficult financial situations. Thus, return of the company's shares during difficult financial situations could be a very sensitive resolution towards the expected results. Consequently, any major changes in the bankruptcy code should be known and prioritized. Lin (2009) and Pindado et al. (2008) defined financial distress as a state in which a company has failed to fulfill its financial obligation and currently heading towards bankruptcy. In this study, financial distress would be used as a factor to avoid and predict when companies fail to fulfill its financial obligation and head towards bankruptcy.

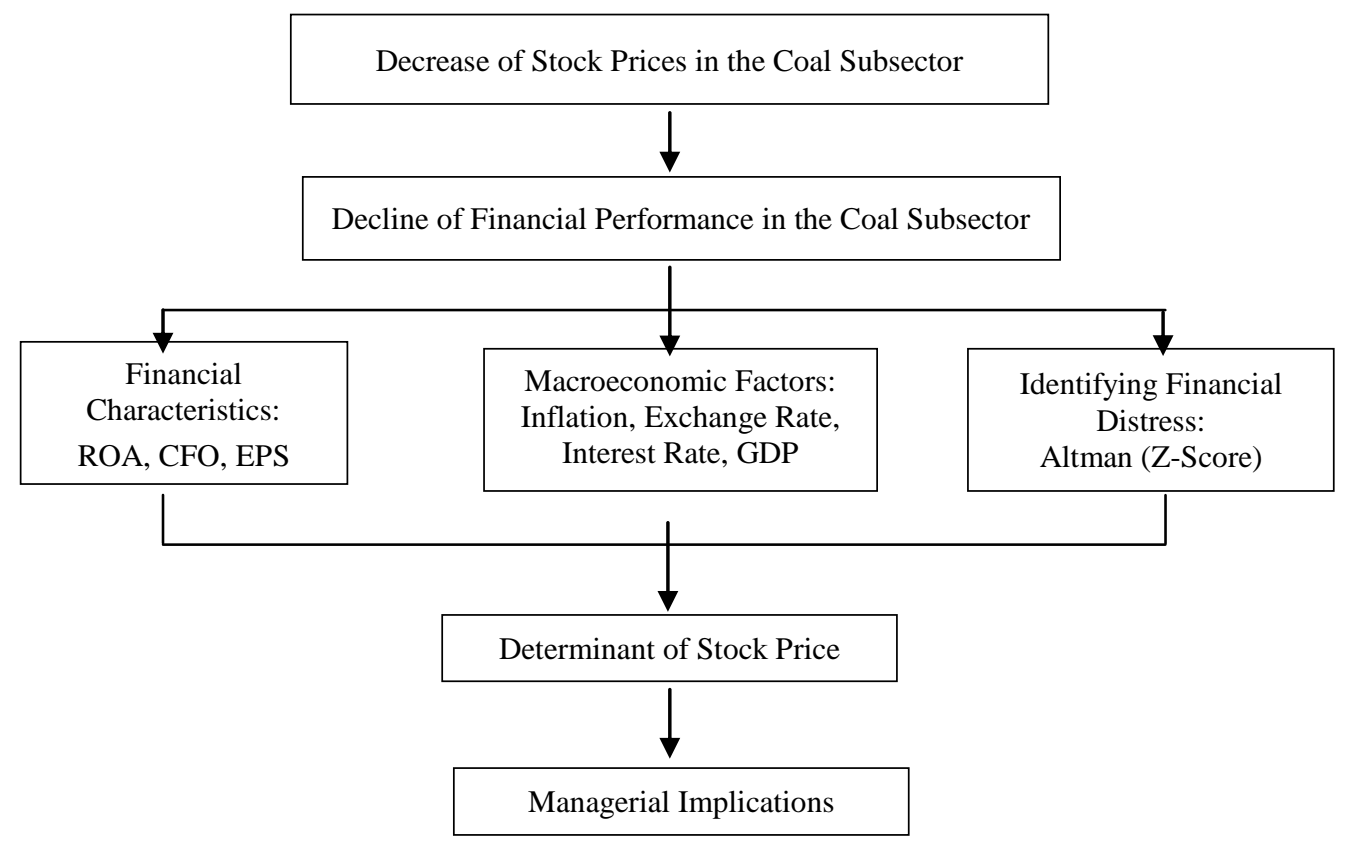

Figure 3 - The Conceptual Frame Work 
A stock is considered as a sign of ownership towards a certain company (Mankiw 2006). Hence, stock price is value of a certain stock during a specific period, which is determined by market players. Stock price is also influenced by the stock's demand and offer within the market, in which a limited liability company would have to be registered in the stock exchange and would be held liable over its own stock. Furthermore, stock price is established from the interaction between the seller and the buyer of the certain stock, in hopes of gaining profit from the stock's company and representing the company's values. The company's stock is highly crucial, especially because it represent the attractiveness of the company to the investors. Brealy et al. (2007) demonstrated that the valuation of stock prices is divided into three groups, which are book value, liquidity value, and market value.

The aim of this study is to analyse the impact of global downturn to company's financial performance and stock price. In the initial phase, each selected company's financial characteristics and financial distress conditions will be described. Furthermore, additional information will be gathered to determine factors that could affect stock prices. After obtaining that information, this study would then compare several factors such as financial characteristics, financial distress, and stock price from 2013 until 2017. Figure 3 shows the conceptual framework used in this study.

\section{METHODS OF RESEARCH}

The data for the present study were drawn from mining companies operating in the coal subsector that are registered in BEI, fulfilling a certain criteria from 2013 until 2017. In addition, companies would also need to publish detailed financial statements each year from 2013 until 2017. Hence, the sample consisted of eleven companies, which are Adaro Energy (ADRO), Atlas Resourses (ARII), Baramulti Susessarana (BSSR), Delta Dunia Makmur (DOID), Golden Energy Mines (GEMS), Harum Energy (HRUM), Resource Alam Indonesia (KKGl), Samindo Resources (MYOH), Petrosea (PTRO), Golden Eagle Energy (SMMT), and Toba Bara Sejahtera (TOBA).

Data collected was analysed using descriptive and inferensia analysis. Financial distress was measured using Altman's Z-score model and panel data regression, which was run through using software Eviews 9. The panel data regression technique used in this study is the Fixed Effect Model, after using several approaches and test such as the Chow Test, Hausman Test, and the classic assumption test.

There are several stages of analysis to answer the problems in this study, which consists of:

Descriptive analysis to illustrate the financial charactertistic with variables such as ROA, EPS, and CFO gathered from financial statements of selected mining companies operating in the coal subsector that are registered in BEI from 2013 until 2017.

Analysis to identify whether financial distress exists within a certain mining company operating in the coal subsector that is registered in BEI from 2013 until 2017. Financial distress is analysed using Altman's Z-score model, corresponding accordingly to Wahyuni et al. (2016) and Lestari et al. (2016) researches:

$$
\text { Z-Score }=6,56 \mathrm{X} 1+3,26 \mathrm{X} 2+6,72 \mathrm{X} 3+1,05 \mathrm{X} 4
$$

Where: Z-Score is Bankruptcy Index, $\mathrm{X} 1$ is Working capital / total asset, $\mathrm{X} 2$ is Retained earning / total asset, X3 is Earning before interest and taxes/total asset, X4 is Book value of equity/book value of total debt.

Classification of financial distress condition: If $Z>2.6$, it is considered within the "Safe Zone", if $1.1<Z<2.6$ it is considered within the "Grey Zone", and if $Z$ ' $<1.1$ it is considered within the "Distress Zone".

Analysis of the effects of financial performance, financial distress, and macroeconomic factors towards stock price of mining companies operating in the coal subsector that are registered in Indonesia Stock Exchange (BEI) from 2013 until 2017 to illustrate how the aforementioned variables correlate and affects stock prices. Hence, this study will use a 
stock price factor model accordingly to Wahyuni et al. (2016) and Lestari et al. (2016) researches:

$$
\begin{gathered}
Y_{\text {it }}=\beta_{0}+\beta_{1} Z \text {-Score }+\beta_{2} R O A+\beta_{3} E P S+\beta_{4} C F O+\beta_{5} I R+\beta_{6} E R+\beta_{7} I N F+\beta_{8} E G+\text { eit } \\
\beta_{1}, \beta_{2}, \beta_{3}, \beta_{4}, \beta_{8}>0 ; \beta_{5}, \beta_{6}, \beta_{7}<0
\end{gathered}
$$

Where: $Y$ is the stock price, $i$ is the order of the companies oberserved, $t$ is the period (timeline), $\beta_{0}$ is intercept (konstanta), $ß 1-\beta 8$ are regression coefficient, e is the error factor, Z-Score represent financial distress index, ROA is the ratio of net income by total assets, EPS is net income divided by available shares (US\$), CFO is the cash netto earned from the company's operational activities (US\$), IR is the interest rate (\%), ER is the currency rate $(\mathrm{Rp} / 1 \mathrm{US} \$)$, INF is the level of inflation (\%), and EG is Indonesia's economic growth (\%).

\section{RESULTS OF STUDY}

Return on Asset (ROA) shows the company's ability in generating profit or net income over the total assets that the company has. The higher the ROA indicates that the company is able to generate higher levels of net income. Wahyuni (2016) explained that a positive value of ROA illustrates that a company is able to work efficiently; squeezing the most out of the limited resources available. Hence, the higher the ROA, the higher earnings the company would receive. On average, the highest ROA gathered from the sample comes from BSSR, with an ROA of 9,58\%. However, the lowest value comes from ARII, with an ROA value of $3,30 \%$. Other companies such as ADRO, ARII, DOID, GEMS, PTRO and SMMT sits below the average of ROA gathered from the sample. The lowest ROA occurred during 2013 until 2016. This aligns with the decline of net profit of the selected companies during that particular period, which was resulted from the downfall of HBA and global market demand. The highest ROA was obtained by BSSR through efforts of improving their performance by focusing on the Indian market to compensate the decline of demand in China. In addition, BSSR also cut some costs by shipping their own coal.

Earning per share (EPS) is the market value ratio that reflects a company's ability to generate net income for every each share available in the market. On average, the highest EPS gathered from the sample comes from ADRO with a value of US $\$ 0,19$ and the lowest value comes from ARII with a value of US\$-0,02. Other companies such as ARII, BSSR, DOID, GEMS, HRUM, KKGI, PTRO and SMMT are issuers that acquired the value of EPS below the average. ADRO's EPS value has set a high standard for other companies to attain, which is why other companies sits below the average.

Table 2 - Results of the descriptive analysis of Financial Characteristics Variables of mining company's operating in coal subsector condition that are registered in BEI from 2013 until 2017

\begin{tabular}{ccccc}
\hline NO. & EMITEN & ROA & EPS & CFO \\
\hline 1 & ADRO & 3,10 & 0,19 & 432,91 \\
2 & ARII & $(3,30)$ & $(0,02)$ & 3,53 \\
3 & BSSR & 9,58 & 0,01 & 23,24 \\
5 & DOID & 0,91 & $(0,01)$ & 97,79 \\
6 & GEMS & 4,73 & 0,01 & 21,04 \\
7 & HRUM & 3,73 & 0,01 & 29,50 \\
9 & KKGI & 7,22 & 0,01 & 9,05 \\
10 & MYOH & 8,01 & 0,02 & 20,58 \\
12 & PTRO & 0,43 & $(0,00)$ & 42,76 \\
13 & SMMT & $(0,35)$ & $(0,00)$ & $(1,07)$ \\
14 & TOBA & 6,19 & 0,02 & 20,28 \\
\hline \multicolumn{5}{c}{ Standard Deviation } \\
\multicolumn{2}{c}{ Mean } & 3,66 & 0,02 & 63,60 \\
\hline
\end{tabular}

The highest average CFO value was achieved by ADRO with a value of US $\$ 432.91$, whereas the lowest CFO value was attained by SMMT with a value of US\$-1.07. Low levels of CFO reflect the company's ability to invest in others and pay out dividends from their 
operational activities. Oroud (2017) explained that CFO serves as a tool or medium to pay out dividends and capital expenditures. Almost all selected companies acquired a CFO value below the mean, due to the high levels of CFO levels set by ADRO.

Table 2 shows the results (value) of each financial performance variables using the descriptive analysis for each company by using the mean value from 2013 until 2017.

Financial distress is a condition where a company is experiencing financial difficulties or crisses, shown by its inability to pay and distribute their obligation to the stakeholders. Sun et al. (2014) stated that financial distress can be defined as a condition where a company has financial struggles, such as being unable to pay off their debts, excessive account withdrawal, and bank deposit overdraft.

Table 3 - Mean score of Z-Score and the mining company's operating in coal subsector condition that are registered in BEI from 2013 until 2017

\begin{tabular}{cccccc}
\hline NO. & EMITEN & Z-Score & Safe-Zone (kali) & Grey-Zone (kali) & Distress-Zone (kali) \\
\hline 1 & ADRO & 3,15 & 18 & 2 & 0 \\
2 & ARII & $(2,83)$ & 0 & 0 & 20 \\
3 & BSSR & 2,89 & 10 & 5 & 5 \\
5 & DOID & 1,62 & 0 & 16 & 4 \\
6 & GEMS & 5,74 & 20 & 0 & 0 \\
7 & HRUM & 11,89 & 20 & 0 & 0 \\
9 & KKGI & 9,31 & 20 & 0 & 0 \\
10 & MYOH & 5,28 & 20 & 0 & 0 \\
12 & PTRO & 3,01 & 17 & 3 & 10 \\
13 & SMMT & 2,82 & 6 & 12 & 2 \\
14 & TOBA & 2,43 & 6 & & \\
\hline
\end{tabular}

Table 3 showed the descriptive analysis by showing the mean score and the financial condition using the Altman Z-score method from 2013 until 2017. Companies that fall within the Safe-Zone consist of ADRO, BSSR, GEMS, HRUM, KKGI, MYOH, PTRO and SMMT. Companies that falls into the Grey-Zone are DOID and TOBA. Furthermore, only one company that falls into the Distress Zone, which is ARII.
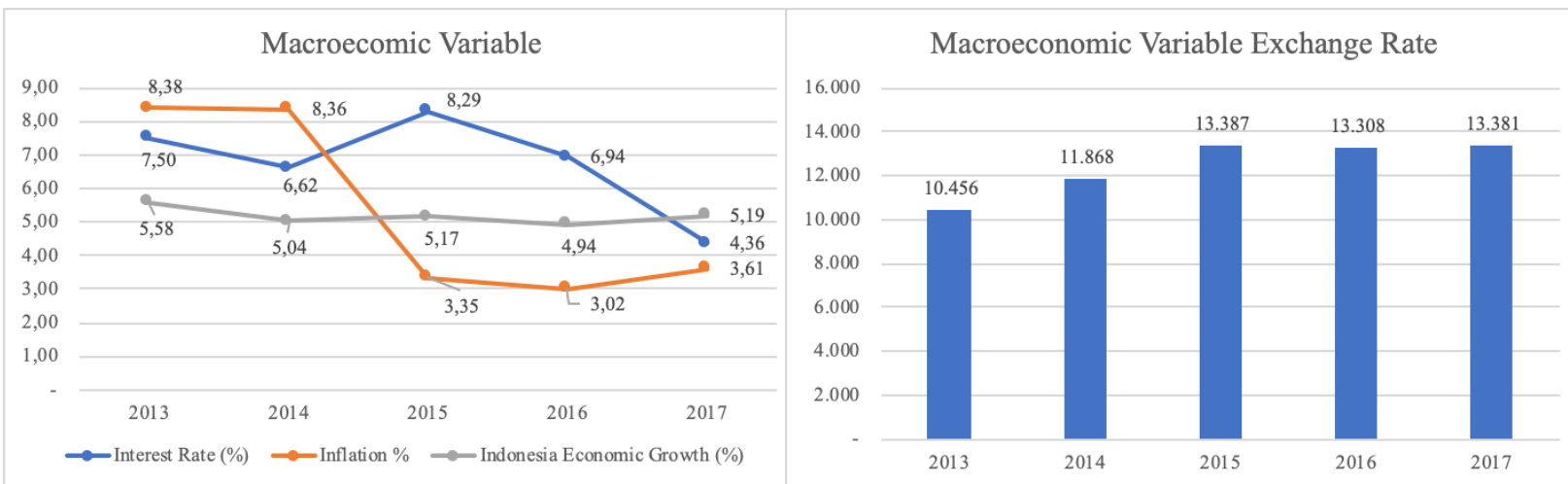

Figure 5 - Macroeconomic Factors from 2013 until 2017

From 2013 until 2017, almost all companies experienced fluctuation of Z-score value and falls in different zones. Companies that consistently stayed in the Safe-Zone are GEMS, HRUM, KKGI, and MYOH. Furthermore, ADRO have falled into the Grey-Zone in quartal I and II of 2013, which was caused by low amount working capital during that period. On the other hand, ARII is the only company that consistently stayed within the Distress-Zone from 2013 until 2017, due to negative cumulative retained earning, and negative working capital. Other companies that have experienced both Grey-Zone and Distress-Zone are BSSR, DOID, SMMT dan TOBA. One of the main reasons behind companies falling into the GreyZone and Distress-Zone from 2013 until 2016 is due to the downturn of HBA that was caused by a global economic crisses and decreased the demand for coal. 
The Safe-Zone condition shows that a company is able to pay their short and long-turn debts, generate net profit, and have retained earnings even if the global economic condition is unstable. Results have shown that there are significant fluctuations of interest rate from 2014 until 2015. Nevertheless, Indonesia's economic growth (Gross Domestict Product Growth-EG) did not experience any significant fluctuations from 2013 until 2017. The exchange rate of foreign currency from IDR to US\$ weakened from 2013 until 2015. In 2016 until 2017, the exchange rate was still quite weak, although it did not experience any significant fluctuation. Figure 5 shows the fluctuation of Indonesia's macroeconomic factors.

Fixed Effect Model (FEM) selected as indicators of the best model, as it has been tested through a series choice of model and went through the classic assumption test, which is free from any violation of the assumption of normality, multicollinearity, heteroscedasticity, and autocorrelation. The $\mathrm{R}^{2}$ value obtained was $96.54 \%$, which indicates that $96.54 \%$ of heterogeneity in this study can be explained by factors that affects stock price within the model, wherease $4.46 \%$ can be explained by other factors outside of this model. The Fstatistic of 277,75 with probability value of 0.000 indicates that there is at least one independent variable that has a linear relationship with stock price at the level of $5 \%$.

Table 4 - The effect of Financial Distress, Financial Characteristics, and Macroeconomic Factor on Mining Companies operating in the Coal Subsector that are registered in BEI from 2013 until 2017

\begin{tabular}{cccccc}
\hline & Variable & Coefficient & Std. Error & t-Statistic & Prob. \\
\hline Constant & C & 2.614244 & 0.624696 & 4.184827 & 0.0000 \\
\hline \multirow{3}{*}{ Financial Characteristics } & ROA & $0.011991^{* \star *}$ & 0.001899 & 6.313604 & 0.0000 \\
& EPS & $-0.445744^{* \star *}$ & 0.100428 & -4.438452 & 0.0000 \\
& CFO & $0.000260^{\star \star \star}$ & $6.93 E-05$ & 3.752188 & 0.0002 \\
\hline Financial Distress & ZSCORE & $0.015920^{\star \star \star}$ & 0.004280 & 3.719657 & 0.0003 \\
\hline \multirow{3}{*}{ Macroeconomic Factors } & IR & $-0.026950^{* \star *}$ & 0.009922 & -2.716115 & 0.0072 \\
& INF & $-0.048912^{* \star *}$ & 0.008656 & -5.650968 & 0.0000 \\
& EG & $-0.167424^{* *}$ & 0.067701 & -2.472988 & 0.0143 \\
& ER & $-0.093263^{* \star *}$ & 0.020835 & -4.476329 & 0.0000 \\
\hline
\end{tabular}

Description: ${ }^{* * *}$ significant coefficient $(\alpha)=1 \%,{ }^{* *}$ significant coefficient $(\alpha)=5 \%$.

Source: Data analysis using E-views 9.

Table 4 shows the results of panel data regression analysis, which shows variables of financial characteristics such as Return on Assets (ROA) and Cash from Operation (CFO) have a significant and positive relationship towards stock price. Nonetheless, other financial characteristics variable such as Earning per Share (EPS) has a significant and negative relationship towards stock price. In addition, Z-Score also has a significant and positive relationship towards stock price. Furthermore, other variables including Interest Rate (IR), Exchange Rate (ER), Inflasi (INF) and Economic Growth (EG) have a significant and negative relationship towards stock price.

Return on Asset (ROA) is a ratio that indicates how profitable a company is relative to its total assets. Hence, ROA is calculated by dividing a company's net income by total assets. ROA has been shown to have significant and positive correlation towards stock price. Coefficient size of 0.011991 indicates that an increase of ROA in $1 \%$ would also increase the stock price as much as 0.011991 (thousand US\$), cateris paribus. High levels of ROA would indicate that the company is able to maximize their assets, which could increase the stock price and their attractiveness to investors. The results in this study align with previous literatures from Wahyuni et al. (2016) and Avdalovic and Milencovic (2017).

Cash from Operation (CFO) indicates the amount of money or proft a company brings in from the ongoing regular business activities that the company has, such as providing service or selling goods. CFO has been shown to have significant and positive correlation towards stock price. Coefficient size of 0,00026 indicates that an increase of CFO in 1 million US\$ would also increase the stock price as much as 0,00026 (thousand US\$), cateris paribus. High levels of CFO would indicate that the company is able to pay out their dividends, pay debts, and invest more in other areas, which would affect the company's performance in the long run. Hence, high CFO would also increase the company's 
attractiveness towards investors. This also aligns with previous research conducted by Oroud et al. (2017).

Earning per Share (EPS) is the company's ability to generate net profit for every outstanding share. The earnings per share value are calculated as the net income (also known as profits or earnings) divided by the available shares EPS. The EPS variable has been shown to have significant and negative correlation towards stock price. Coefficient size of -0.445744 means that an increase of EPS in 1 million US $\$$ would decrease the stock price as much as 0.445744 (thousand US\$), assuming cateris paribus. The results in this study align with previous literatures from Avdalovic dan Milencovic (2017).

Z-Score is a combination from several financial ratios, such as Working Capital, Earning before Interest and Tax (EBIT), Retained Earning, and Bookvalue of Equity to Total Debt that are mentioned in a company's financial statements. Hence, this study has found that the Z-Score have a significant and positive correlation towards stock price. Coefficient size of 0.01592 indicates that an increase of Z-score would also increase the stock price around 0.01592 (thousand rupiah), cateris paribus. The higher the Z-score a company has means that they have a healthy financial condition (i.e., within the Safe Zone). Thus, they are able to pay their short and long-term debts, generate net profit, and have retained earning, which could increase the stock price and their attractiveness to the investors. Wahyuni et al. (2016), Apergis et al. (2010), Lestari et al. (2016), and Zhao (2014) researches also showed similar results.

Interest Rate (IR) is one of the macroeconomic factors that was determined by the government to maintain a country's own economic sustainability. IR value that is used as a reference in Indonesia is the $\mathrm{Bl}$ rate. However, starting from $19^{\text {th }}$ August 2016 , it has changed to BI 7-Day Reverse) Repo Rate. Hence, table 21 showed that there is a significant and negative correlation between IR and stock price. Coefficient size of -0.02695 means that an increase of IR in 1\% would decrease the stock prices as much as 0.02695 (thousand US\$), cateris paribus. The higher the interest means that companies would need to pay more of their obligation using interest, which could decrease the net profit. This means that it may decrease the company's attractiveness to investors. This notion aligns with previous literatures of Artha et al. (2014).

Inflation (INF) is one of the macroeconomic factors that reflect how well the country's economic system and current conditions are. Inflation is interpreted as a price increase in general and continuously in a certain period of time (www.bi.go.id). The macroeconomic variable of INF, which revealed a significant and negative relationship towards stock price. Coefficient size of -0.0489 demonstrates an increase of INF $1 \%$, which could decrease the stock price as much as 0.0489 (thousand US\$), cateris paribus. When INF increase and becomes hard to control, then companies would experience an increase of operating costs, which could evidently decrease the company's net profit and lead to a decrease of stock price. This notion aligns with previous literatures of Al-Shubiri (2010) and Wahyuni et al. (2016).

Exchange Rate (ER) is a comparison between the values of one country's currency to another. Table 21 shows that ER has a significant and negative correlation with stock price. Coefficient size of -0.09326 means that there is an increase of ER as much as 1 thousand rupiah, which could decrease the stock price around 0.09326 (thousand US\$), cateris paribus. The results align with Artha et al. (2014) and Pardede et al. (2017) research.

Economic Growth (EG) is a process of changing the financial condition of a country continuously towards better conditions for a certain period. Economic improvement can also be interpreted as a process of increasing production capacity produced in the form of increasing national income. The existence of economic growth is an indication of increasing economic development in people's lives. The macroeconomic variable of EG correlates significantly and negatively towards the stock price. EG coefficient of -0.1674 means that an increase in EG of $1 \%$ would decrease the stock price around 0.1674 (thousand US\$), ceteris paribus. Those results does not align with previous literatures that have been conducted by Raza et al. (2015) which described that EG has a significant and positive relationship. The discrepancies shown in various previous literatures are resulted from the characteristics of 
the business in the research. The research subject is mining companies operating in the coal subsector, in which their main target is to operate in the international market (export). Export commodity has an average composition of above $80 \%$ compared to being used domestically, with China as their main destination. From 2013 until 2017, economic growth in Indonesia was considered relatively stable and did not experience any significant fluctuation. The average $E G$ is $5,18 \%$, with the highest $E G$ of $5,19 \%$ that occurred in 2017 . The lowest $E G$ of $4,94 \%$ occurred in 2016 . Contrary to the growth of the coal subsector, especially during 2013 until 2016, that declined drastically due to low demand in the international market, mainly from China. Low demands caused the downfall of HBA. Furthermore, the decline of financial performance (i.e., loss of profit) of mining companies operating in the coal subsector has also caused the stock prices of companies to weaken.

\section{MANAGERIAL IMPLICATIONS}

A company's management had done numerous efforts in order to maintain their financial performance, so that they could improve their stock price. This research has shown that financial characteristics, Z-score, and macroeconomic factor could affect a company's stock price. Thus, the managerial implication of this research is to focus on acknowledging whether the company has experienced a decline in financial performance and Z-score, which can lead to a decline of stock price.

When investor is planning to invest in a certain company, they would analyse the company's financial characteristics, financial distress, and macroecomic factors as basic elements that needs to be considered. Internal factors such as ROA and CFO can be analysed directly from the company's financial statements. However, Z-score are not available in the financial statements, which mean that investors could calculate on their own. Furthermore, in-depth analysis of macroeconomic factors are adjusted to the company's characteristics such as whether they are a company that need large capital, or an exporting company that is affected by economies within the country of destination.

The government has an interest in determining each of its policies to become a stable and increasing national economic growth which in turn can prosper the people of Indonesia. For example, Ministry of Energy and Mineral Resources designed mining policies through the Mining Law. The policies issued are expected to be sustainable and provide a guarantee of the business continuity. Government policy will greatly affect the company in determining the business direction of the company such as export policies where the market composition of the market is mostly international (export) markets, smelter policies that require very large working capital and IUP (mining business permit) policy which will ultimately affect the company's financial performance. Bank of Indonesia $(\mathrm{BI})$ is an institution implementing monetary policy in the State of Indonesia. $\mathrm{BI}$ is expected to be able to maintain the stability of the rupiah's value, both the stability of the prices of goods and services reflected in the development of inflation rates, the development of the rupiah exchange rate against other currencies, and the $\mathrm{BI}$ rate (interest rate) expected to influence market interest rates interbank money and longer term of interest rates. The last one is Financial Services Authority $(\mathrm{OJK})$ is an institution that function to organize an integrated system of regulation and supervision of all activities in the financial services sector both in the banking sector, capital market, and non-bank financial services sectors such as Insurance, Pension Funds, Financing Institutions, and other Financial Services Institutions. Government's policy of providing guarantees and sustainability can improve company performance and stock prices. This can encourage more investment to come to this country.

\section{CONCLUSION}

Based on the results and analysis that have been conducted, ADRO and KKGI are considered to have one of the best financial performances for mining companies operating in the coal subsector that are registered in BEl. This was determined by analyzing ADRO and KKGl's positive ROA, EPS, and CFO during 2013 until 2017. In addition, this study has 
acknowledged that mining companies operating in the coal subsector that are registered in BEI have gone through various financial distresses throughout 2013 until 2017. Companies that are consistently within the safe-zone are GEMS, HRUM, KKGI, and $\mathrm{MYOH}$. On the other hand, ARII was the only company that consistently stayed within the distress-zone from 2013 until 2017. Financial characteristics such as ROA, CFO, and Z-score have a significant and positive correlation towards stock price. However, macroeconomic factors such as IR, ER, INF, and EG have a significant effect and correlates negatively towards stock price. EG, which has a negative effect, should be considered as the main object of concern due to its natural relationship with companies that export main commodities to the international market.

\section{REFERENCES}

1. Apergis N, Sorros J, Artikis P, Zisis V. 2011. Bankruptcy Probability and Stock Prices: The Effect of Altman Z-Score Information on Stock Prices Through Panel Data. Journal of Modern Accounting and Auditing 7 (7): 689-696.

2. Artha DR, Achsani NA, Sasongko H. 2014. Analisis Fundamental, Teknikal Dan Makroekonomi Harga Saham Sektor Pertanian. Jurnal Manajemen Dan Kewirausahaan, 16 (2) : 175-184.

3. Avdalovic SM, Milenkovic I. 2017. Impact of company performances on the stock price: An empirical analysis on select companies in Serbia. Economics of Agriculture 2 (64):561-570.

4. Batubara [internet] [Diunduh pada 6 Pebruari 2019] tersedia pada https://www.indonesiainvestments.com/id/bisnis/komoditas/batu-bara/item236?

5. [BI] Bank Indonesia. 2018. BI SSKI Eksternal [internet]. [Diunduh pada 5 Pebruari 2019]. Tersedia pada http://www.bi.go.id/id/.

6. [BPS] Badan Pusat Statistik. 2016. Laju pertumbuhan y on y produk domestik bruto menurut lapangan usaha (persen) 2014-2016 [internet]. [Diunduh pada 5 Pebruari 2019]. Tersedia pada https://www.bps.go.id/dynamictable/.

7. Lestari SD, Oktaniani RF, Arafah W. 2016. Financial distress prediction with altman zscore and effect on stock price: empirical study on companies subsectors chemical listed in Indonesia stock exchange Period 2009-2014. International Journal of Business and Management Invention. 5(8):30-39.

8. Oroud YS, M Islam A.Md, Tunku Salha T.A. 2017. The Effect of Cash Flows on the Share Price on Amman Stock Exchange. American Based Research 6 (7): 22-28.

9. Pardede N, Hidayat RR, Sulasmiyati. (2016). Pengaruh Harga Minyak Mentah Dunia, Inflasi, Suku Bunga (Central Bank Rate), dan Nilai Tukar (Kurs) terhadap Indeks Harga Saham Sektor Pertambangan di ASEAN (Studi pada Indonesia, Singapura, dan Thailand Periode Juli 2013-Desember 2015). Jurnal Administrasi Bisnis (JAB) 39 (1) 130-138.

10. Perdana R, Darminto, Sudjana Nengah. 2013. Pengaruh Return On Equity (ROE), Earning Per Share (EPS), Dan Debt Equity Ratio (DER) Terhadap Harga Saham (Studi Pada Perusahaan Makanan dan Minuman yang Go Public di Bursa Efek Indonesia Periode 2008-2011). Jurnal Administrasi Bisnis (JAB)| 2 (1) Mei: 128-137.

11. Raza SA, Jawaid ST, Afshan S, Karim MZA. 2015. Is Stock Market Sensitive to Foreign Capital Inflows and Economic Growth? Journal of Chinese Economic and Foreign Trade Studies, 8 (3):142-164.

12. Sun J, Li H, Huang QH, He KY. 2014. Predicting financial distress and corporate failure: A review from the state-of-the-art definitions, modeling, sampling, and featuring approaches. Knowledge-Based Systems, 57: 41-56.

13. Wahyuni F, Anggraeni L, Irawan T. 2016. Financial distress and its impact on stock prices of mining sector firms in Indonesia stock exchange. International Journal of Research in Commerce, IT, \& Management 6(12): 59-64.

14. Zhao T. 2015. The relationship between Z-Score and stock prices. [Paper] SSRN. https://papers.ssrn.com/sol3/papers.cfm?abstract_id=2595600. 